\title{
The Role of Internet as a Local Tourism Promotion Strategy
}

\author{
M Iffan ${ }^{1}$, E Farida $^{2}$ \\ \{ $\underline{\text { iffan@email.unikom.ac.id }}^{1}$, evafarida22@mahasiswa.unikom.ac.id ${ }^{2}$ \}
}

Department of Management, Universitas Komputer Indonesia, Indonesia ${ }^{1}$

Faculty of Economics and Business, Universitas Komputer Indonesia, Indonesia ${ }^{2}$

\begin{abstract}
The purpose of this research is to find out how much the internet influence the development of local tourism in Indonesia. This study used the qualitative method through literature studies. The results of this study state that the role of the internet influential the development of local tourism so they can compete with national and foreign tourism. It has been proven that the role of the internet as a local tourism promotion strategy is indeed an effective and efficient alternative compared to other strategies because it has a huge impact on the progress of tourism.
\end{abstract}

Keywords: Tourism, Internet, Management, Social Media, Visitors

\section{Introduction}

Local tourism is a place that needs special treatment in order to promote it, so it will provide more benefits to help the increasing the income of a region [1]. Therefore, the selection of the promotional strategy must be appropriate so that the impact will be relevant and significant. This research was conducted to find out whether promotional strategies carried out using the internet to see the influence of promotion strategy for local tourism.

Since the growth of the internet, travel planning has become one of the main reasons for someone to use the internet. The internet is a medium of information used by almost all institutions, organizations, businesses, and individuals in introducing or promoting products or services. The internet is an application of network systems and services, computers and mass communication that contains technology, policy, rules and administrative content to make it easier for consumers to obtain the information according to their needed such as business, organizations or institutions. Promotion strategies are planning, implementing, and controlling communication from an organization to consumers and other targets [1]. The internet has changed the way information spread about tourism and the way people plan trips [2]. At the same time, the internet also mediates one's tourism experience to visualize, reconstruct, and recall their journey using social media sites [3]. Tourism is a travel activity that is carried out some time from the initial residence to the destination with the reason not to live or find income, but only to fulfill curiosity, spend leisure time or just vacation and other purposes [4]. The internet can provide insight related to tourism; at this time, we cannot ignore the role of social media because it distributes information related to travel. We also need to be prepared with the risk if new media emerges. Therefore, the manager needs to understand the dynamics of the technology so it can compete in the outside world [5]. The website has a big impact on promoting tourist attractions, simply by taking a photo as good as possible and then posting it with an interesting caption that will make people curious. However, because all the promotional activities carried out with the internet, it will be viral fast [6]. The Internet can 
capture every moment of a trip well. Social media is an official media that can be used to communicate with each other; it can be a photo, video sharing site. It will become something popular in a society that is active in social media [7]. Promotion strategies will be successful if there is trust from consumers. Therefore, advertisements or promotions through a photo on the internet must be taken without effect. Thus, consumers will not feel cheated or disappointed [8]. Management and promotion of tourist attractions need to be done to increase visitors by utilizing information technology available is very effective for the continuation of a tourist place [9]. Promotion via the internet will certainly make it easier for consumers or visitors to comment directly in the available column. We need to hear their opinions to be used as motivations for improvement in the future [10].

The purpose of this research is to find out whether the internet is the right way to promote the strategy for a local tourism place and to determine how the internet has a significant influence as well as the progress of local tourism. Usually, local tourism is a natural and unpolluted tourist spot.

\section{Method}

This study used the qualitative method through literature studies from the comparison of the cases that have been studied and published previously. Besides, we used the theoretical foundation of the experts to be a guide so that the results of this study would be more relevant and accurate about the acceptance or rejection of the object that we examined. This study explained the influence of the internet and used it as a strategy to promote local tourism.

\section{Results \& Discussion}

West Java is one of the provinces in Indonesia that has great tourism potential. If it is managed properly, tourism can produce benefits for the country and can enhance economic growth in Indonesia. The tourism sector can encourage the progress of various other production sectors, so both will get the benefit, respectively [2]. Then, it will be a direct contribution to the progress of the region in efforts such as road improvement, port development, and can encourage the implementation of cleaning programs, environmental preservation, and urban rearrangement. Besides, the presence of tourism destinations certainly requires many people to help the management system so it can create a new job opportunity and can reduce much unemployment, increase income, create a new atmosphere. Therefore, the government should be aware of the importance of the promotion aspects of tourism in Indonesia. Promotion is essentially a form of marketing communication and is an important thing that needs to be done in order to achieve a goal [6]. However, because of the rapid growth of information and communication technology progress, it inevitably requires a change in promotion strategy by following the development of the era itself. We must provide information to the people by describing and offering something to attract the attention of consumers in hopes of getting a profitable outcome [7]. In promoting something we need to pay attention to which parts can be used as charms or attraction of the place.

The internet is a popular network that is widely used in this present day. It has become the right choice if we make the internet a local tourism promotion strategy because it is a very effective and efficient alternative [8]. At the moment everything we need is already available on the internet, even when we want to travel, we can also plan the trip via the internet. The way to promote on the internet is varied, including being able to advertise online on YouTube, 
create a blog or WEB address, using social media such as Instagram, Path, Line, and Facebook. Some made special travel planning applications such as Traveloka, Skyscanner, and others. The easiest promotion is through social media because the promotion does not always have to be carried out by the tourism manager. Customers can share information. The advantage of using the internet is the promotion target is wide and can be accessed more quickly and accurately [10]. Social media is an online media that allows its users to directly participate in the promotion process of a tourism destination by forming a forum, for example, wiki or using hashtags on Instagram and so on. In addition to the social media, promotion will have a direct response between potential visitors with the admin so that effective communication can occur between the two. Applications that are popular today and are widely used as promotional media are Instagram applications, where almost everyone has used them because this application is easy to understand.

Here are examples of promotions through Instagram, images taken from Dino Prajabatia's personal Instagram account at his post, around 2017. He has promoted tourism sites through his photographs taken in a new place called "Situ Leutik," indirectly. At that time, visitors were only residents came. The location is not far from his residence, which located in the Cibeureum Village area, Banjar Regency, Banjar City, West Java, Indonesia. When the start is opened, the visitors are only residents. However, through this posting local tourism can be known more widely by others and almost every place has been filled with many visitors who are not only residents. It can be seen in Figure 1, and Figure 2 below is an example of a post that has included one form of promotion via Instagram:

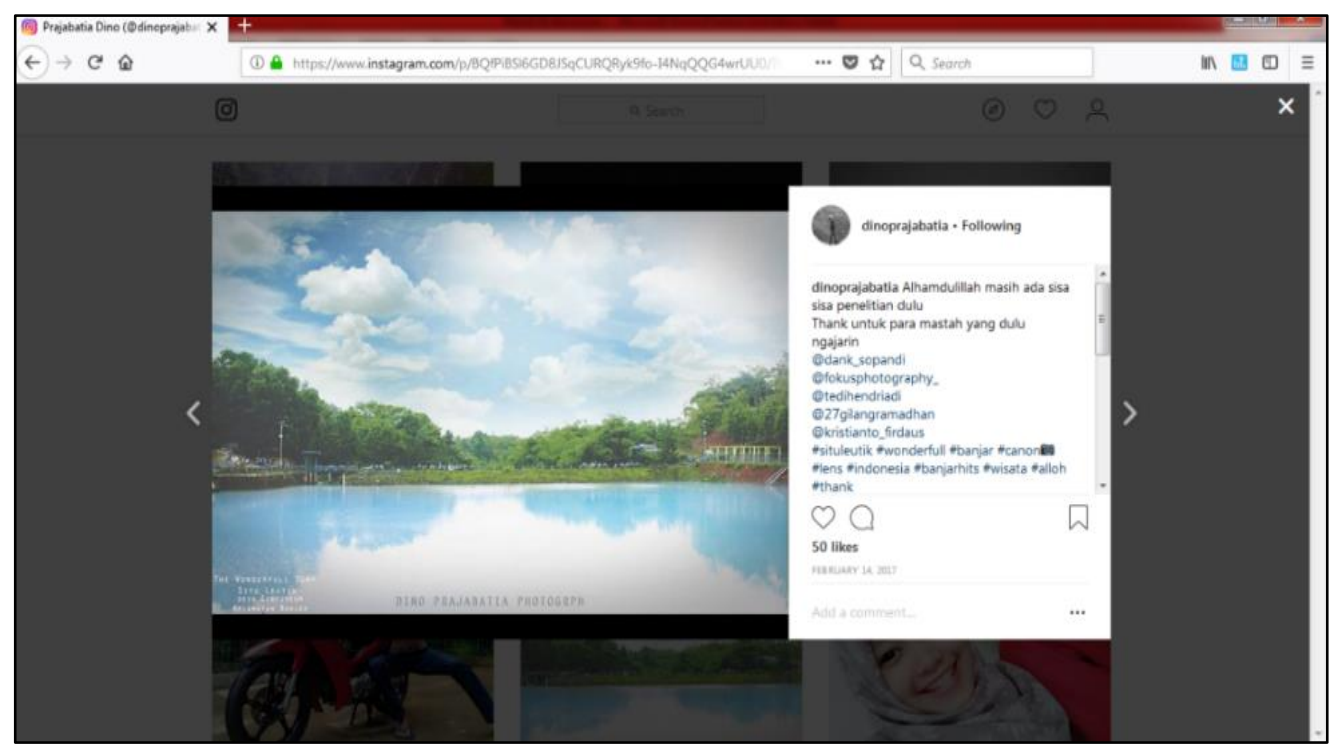

Fig 1. An Example of A Form of Promotion through Instagram Social Media. This Figure was adapted www.instagram.com/dinoprajabatia/ on August 3, 2018.

In Figure 2, the shipment from Daniar Novendas Instagram personal account in the statement said "there is tourism potential in the city of Banjar and is used as a source of agricultural irrigation for the surrounding community. If the government and society appropriately manage, it will be an alternative tourism option in the city Banjar, where the city of Banjar has very few tourist attractions, and the management is also lacking. 


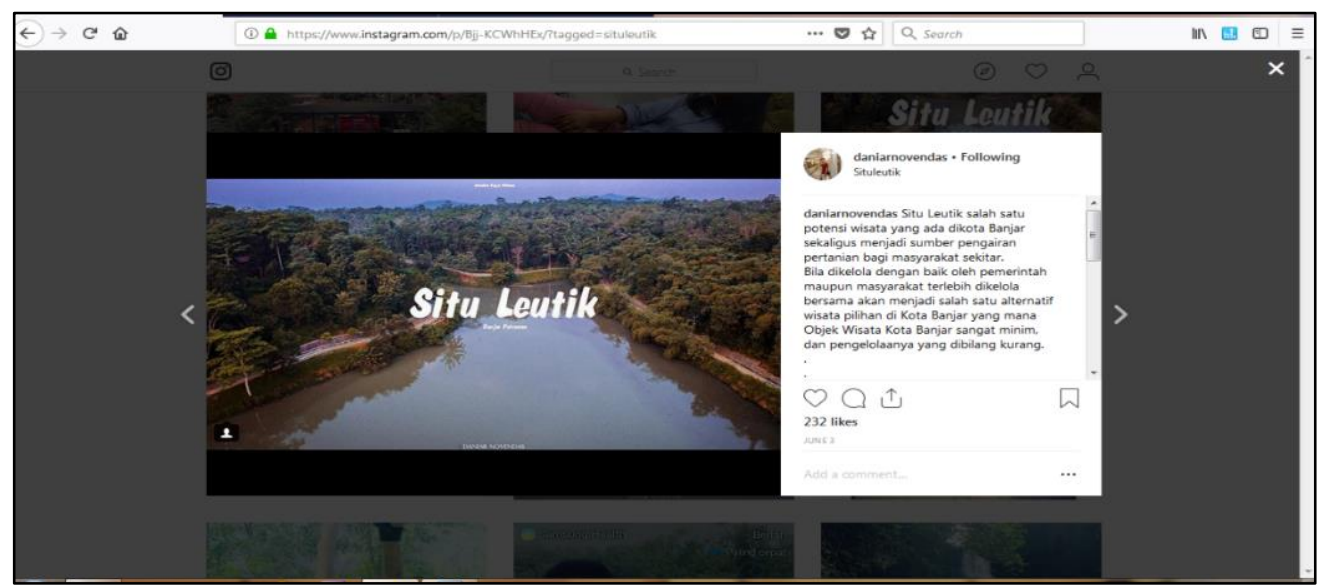

Fig 2. Promotions Carried Out Indirectly by Visitors / Tourism Actors. This Figure was adapted from www.instagram.com/daniarnovendas/ on August 3, 2018.

The image below is an example of promotion through hashtags. In addition to being a form of promotion, users who are active on social media hashtags are also useful for increasing popularity and can make it easier for people to find us when the hashtags we use are popular in search. Hashtags are made according to conditions and promotional needs. The example can be seen in Figure 3 below.

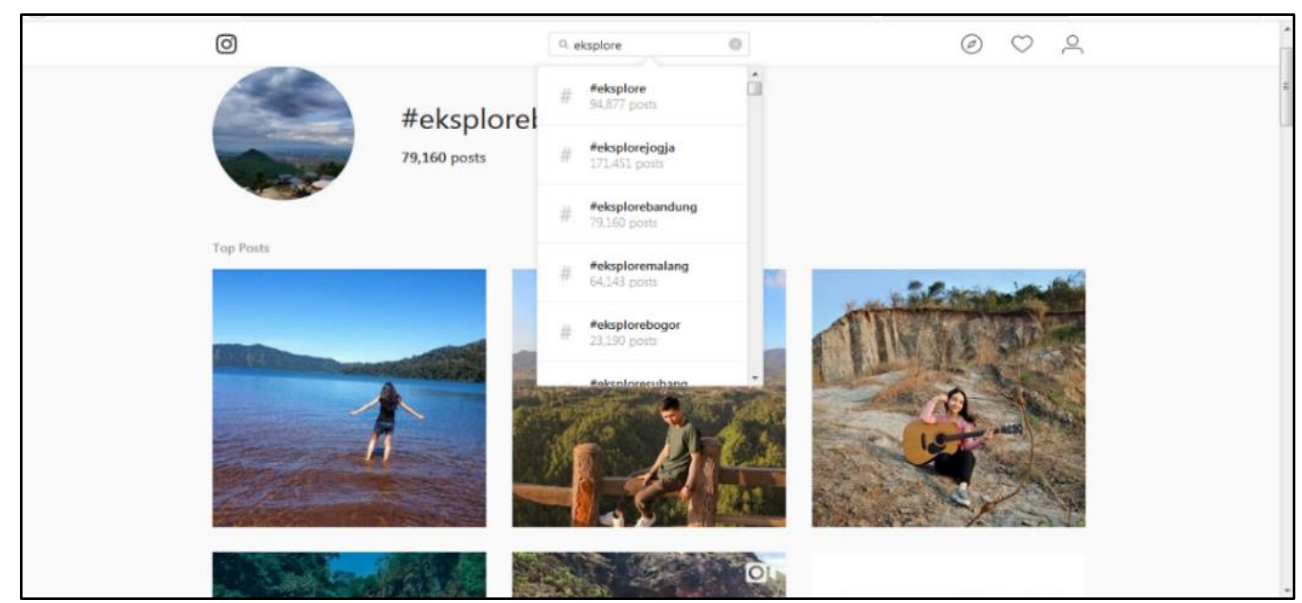

Fig 3: Examples of Indirect Promotions Using Hashtags. This Figure was adapted from https://www.instagram.com/explore/tags/explore/ on August 3, 2018.

If some of the images above are examples of promotions that are done accidentally, then it is different from the example below. This account is intentionally made with the name "explore Pangandaran" and is managed only by an admin. There is specific information about the local tourism site itself, not only posting the picture but through the caption can also find an explanation of the place. In addition to Pangandaran beach, other tourist attractions that are still nearby are also promoted through the same account so that it can provide more and wider 
benefits and impacts on the development of the environmental progress. For example like Figure 4 below.

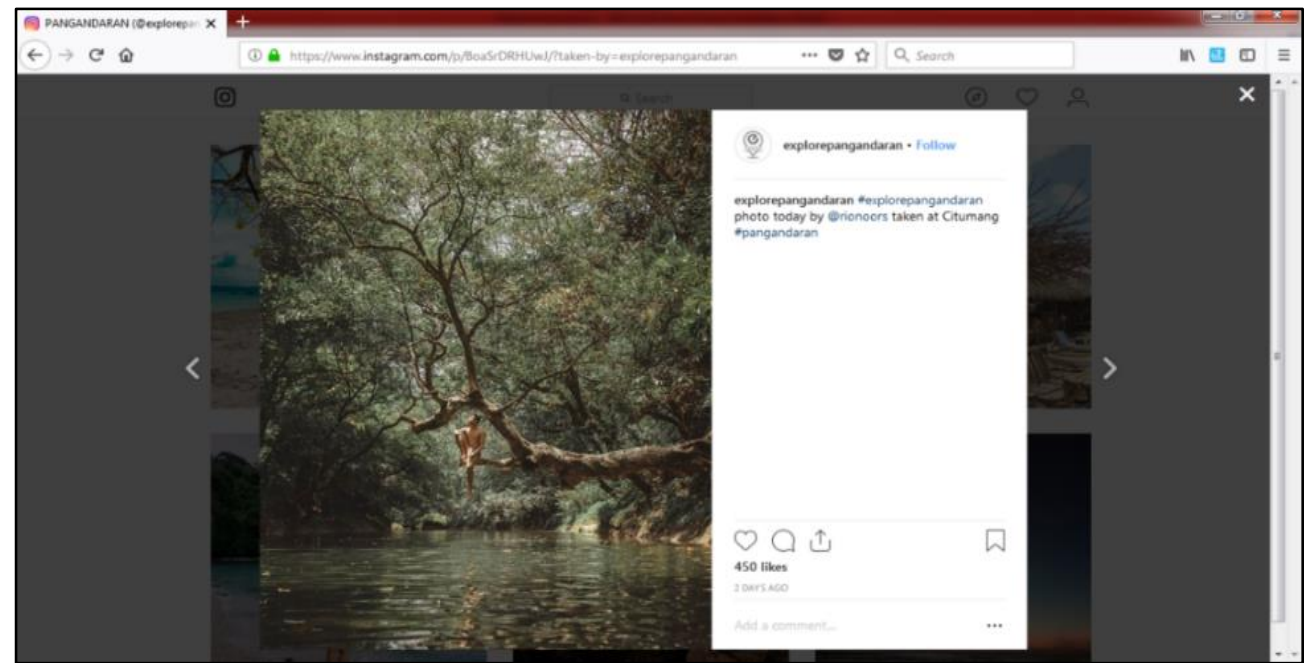

Fig 4. A Deliberate Promotion Made By Creating a Special Account Exploring Certain Tourism Places. This Figure was adapted from www.instagram.com/explorepangandaran/ on August 4, 2018.

Another example of promotion is making an application. This application is designed specifically for tourism planning, for example, Traveloka, Skyscanner, and others. This application is popular in the public. Their potential tourists can get various tourist recommendations according to the destination where we will go. Besides, this application is made not only for the promotion of tourist destinations but also has more benefits because it includes all tourism planning needs from tickets, hotels and so on. Other options may be needed, so you do not need to be tired of arranging it. This application is easy to understand and easy to use because it already has a variety of language choices. It can be seen in Figure 5 for an example of a Traveloka application. 


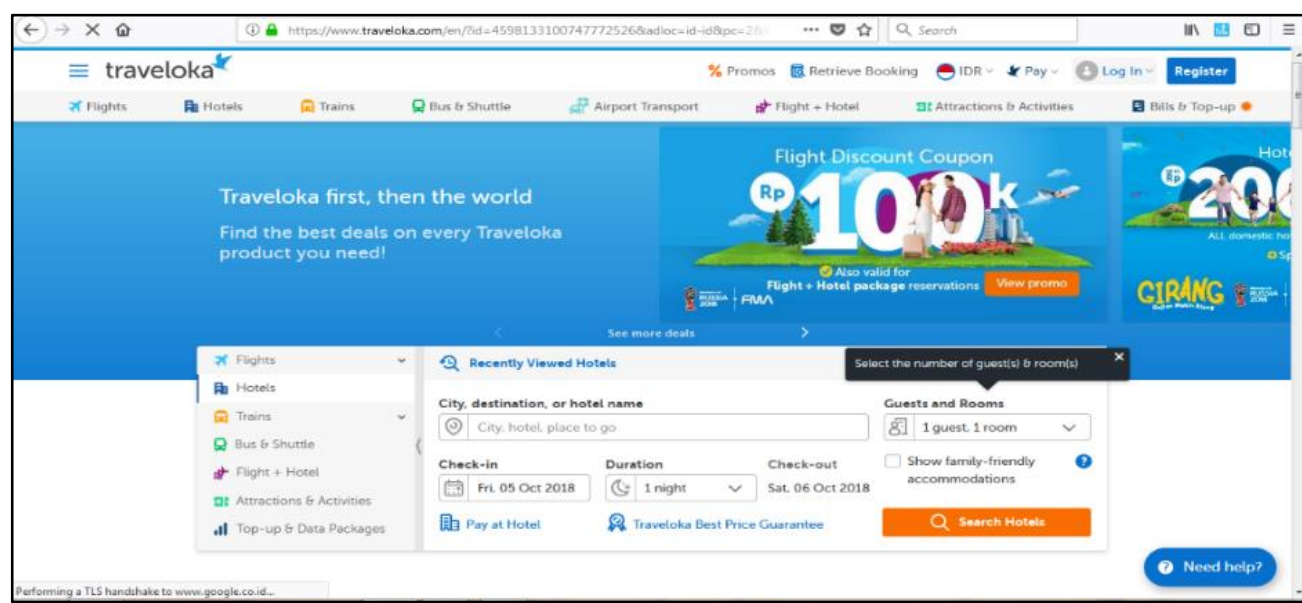

Fig 5. The Initial View of The Traveloka Application, The Contents There Are Various Menus and Options That Cover All Tourism Needs. This Figure was adopted from www.traveloka.com/ on August 7,2018

Just like Traveloka, this Skyscanner application also provides recommendations for various tourist attractions to prospective tourists according to the place you want to go. That way, it can make it easier for us. Figure 6 is an example menu and several options in the Skyscanner application:

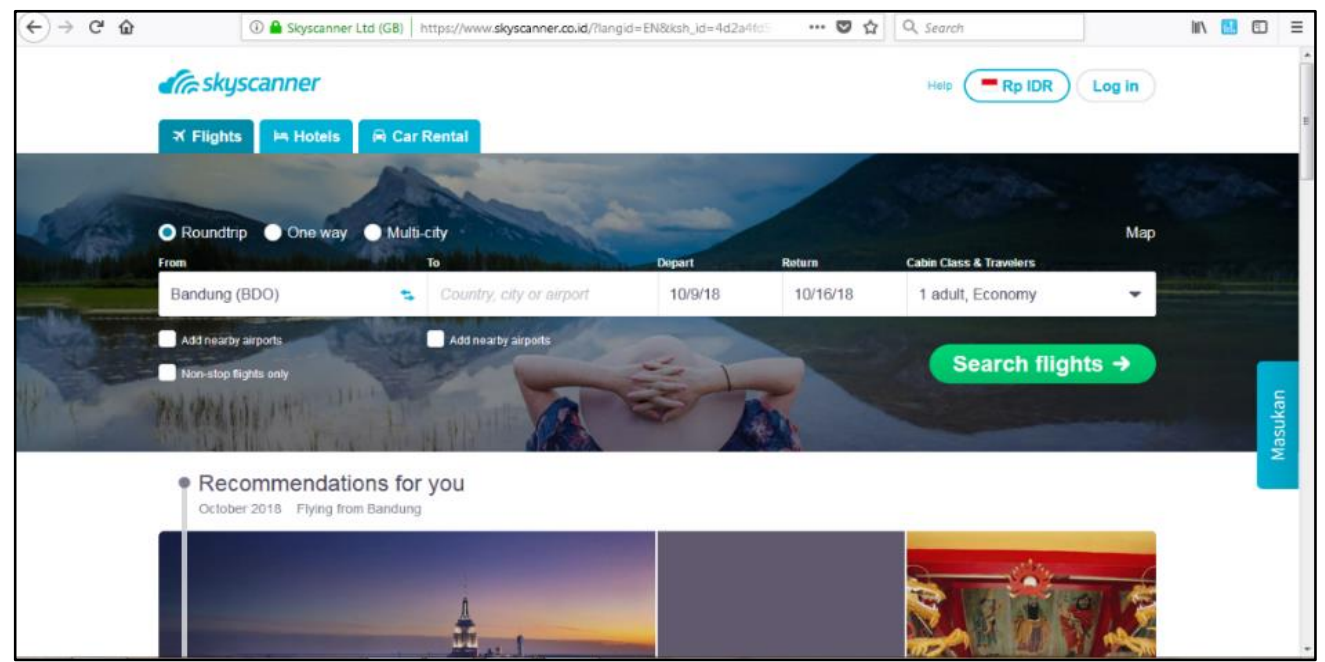

Fig 6. Initial Display of The Skyscanner Application. This Figure was adopted from www.skyscanner.co.id/ on August 7, 2018.

From some of the supporting theories and previous studies that we read, it can be concluded that the internet has indeed greatly affected the development of local tourism progress. The internet provides many conveniences and cheaper, as well as save time and energy. So, it is 
very effective to be used as a promotion tool. The results of this study state that the role of the internet is very influential in the development of local tourism.

\section{Conclusion}

The internet has a significant impact on the progress of local tourism and is the right, effective and efficient strategy choice when viewed in terms of cost, time, energy when compared to other promotional methods that are done offline. Even so, promotion still cannot rely on one method so that the results can be more satisfying.

\section{Acknowledgments}

This research supported by Universitas Komputer Indonesia, in particular, Prof. Dr. Ir. Eddy Soeryanto as the chancellor of the Universitas Komputer Indonesia who has helped provide material and information so that this article can be completed properly. We also do not forget to thank our friends who participated in this research.

\section{References}

[1] Oosterbeek, H., Van Praag, M., \& Ijsselstein, A.: The impact of entrepreneurship education on entrepreneurship skills and motivation. European economic review, 54(3), 442454. (2010)

[2] Buhalis, D., \& Law, R.: Progress in information technology and tourism management: 20 years on and 10 years after the Internet-The state of eTourism research. Tourism Management, 29(4), 609-623. (2008)

[3] Pudliner, B. A.: Alternative literature and tourist experience: Travel and tourist weblogs. Journal of tourism and cultural change, 5(1), 46-59. (2007)

[4] Supandi, A. F., \& Hadi, F.: The development of halal ecotourism of Santen Banyuwangi Beach. University-community engagement. October 8-10, 2018, 3(1), 1. (2018)

[5] Xiang, Z., \& Gretzel, U.: Role of social media in online travel information search. Tourism Management, 31(2), 179-188. (2010)

[6] Lin, Y. S., \& Huang, J. Y.: Internet blogs as a tourism marketing medium: A case study. Journal of Business Research, 59(10-11), 1201-1205. (2006)

[7] Xiang, Z., Wang, D., O'Leary, J. T., \& Fesenmaier, D. R.: Adapting to the internet: trends in travelers' use of the web for trip planning. Journal of Travel Research, 54(4), 511527. (2015)

[8] Aguirre, E., Mahr, D., Grewal, D., de Ruyter, K., \& Wetzels, M.: Unraveling the personalization paradox: The effect of information collection and trust-building strategies on online advertisement effectiveness. Journal of Retailing, 91(1), 34-49. (2015)

[9] Huang, Y. C., Backman, K. F., Backman, S. J., \& Chang, L. L.: Exploring the implications of virtual reality technology in tourism marketing: An integrated research framework. International Journal of Tourism Research, 18(2), 116-128. (2016)

[10] López, M., \& Sicilia, M.: Determinants of E-WOM influence: the role of consumers' internet experience. Journal of theoretical and applied electronic commerce research, 9(1), 28-43. (2014) 